\title{
Forced Execution of Judicial Decisions as the Right to Fair Trial Applicability of this Principle in the Albanian Practice Cases that are handled by the Constitutional Court
}

\author{
PhD. Ina Foto Barjamaj ${ }^{1}$ \\ PhD candidate, Institute for European Studies \\ University of Tirana, Albania \\ E-mail:ina.puravelli@yahoo.com
}

Prof. Ass. Dr. Alba Robert Dumi²

Dean of Graduate School, "Ismail Qemali"Vlore University, Albania University of Tirana, Albania,Management Department

Email:besi.alba12@gmail.com

\section{Doi:10.5901/mjss.2013.v4n9p458}

\section{Abstract}

The degree of emancipation and development of a society depends on the respect and implementation of individual rights and the rule of law. Affirmation of the right would be a formality if the guarantee did not exist mechanisms for their implementation. Human rights are diverse and vary from their nature. One of the most fundamental rights that is envisaged in Article 42 of the Constitution, is the right to a fair trial. This study will focus on analyzing the legal framework as well as its material and procedural relating to a very important stage that of the execution of the law. Because a justice delayed is justice denied.

Analysis and identification of obstacles and causes of non-execution of court decisions that have become final, thus constituting executive titles aiming at finding effective instruments to which the correct and prevent making the execution process more productive. Referring to the jurisprudence of the Constitutional Court and the European Union. The study requires reforming and improving the legal framework, but above all the institutional framework to enable the execution of judicial decisions as part of the right to a fair trial, as well as the importance and consequences of-non-enforcement. Satisfactory implementation of judicial decisions would testify for the well functioning of the rule of law and its basic principles, a fact which is very important especially in Albanian society, also in the context of integration into the European Union standards.

Keywords: Obligatory Execution, Right to fair trial, Violation of law, Human rights, Court, EU Criteria

\section{Introduction}

Implementation of human rights is a key element for democratization and showing the operation of society and the development of the rule of law. ${ }^{1}$ The rule of law as one of the fundamental principles of a democratic society contains in itself the obligation of public authorities to implement commands or judicial decisions final. One of the main rights which constitute the core of this paper is "The right to a due legal process", which is enshrined in Article 42 of the Constitution of the Republic of Albania and Article 6 of the European Convention on Human Rights and Freedoms . Each individual must be familiar with his right to a fair trial which guarantees the right of individuals to fair hearing and adjudication of the case by the court, but not only. For this reason the last instance for reviewing claims for alleged violations of due process is the Constitutional Court. Regular process forms the basis of individual complaints which are reviewed by the Constitutional Court.

Based on the Constitution of Albania:"The Constitutional Court decides on the final judgment of the individual complaints about violations of their constitutional rights to a fair hearing, after having exhausted all legal remedies to protect these rights.In many cases Albanian citizens who have acquired a right that was denied or violated lose time in different offices just to get that which verdict is legally recognized. ${ }^{2}$ The execution of a final decision of the court is

1 Vendim i GJEDNJ Hasan dhe Chaus kundër Bulgaria, Nr. 30985/96, pg 87

2 Vendimi i Gjykatës Kushtetuese të Republikës së Shqipërisë nr. 43 datë 19.12.2007 
considered as the final stage of implementation of law judicially acquired. Only after completion of this phase can be considered that the individual has fully set in place his right. The whole judicial process, often difficult and problematic, there would be no value if not followed by a process that connects directly to the bailiff offices, with its execution or realization of an acquired right.

The aim is to critique in order to meet gaps in legislation concerning legal regulation of executive relations. Defining a new approach to promote debate on various issues related to the full and timely execution court decisions, through measures to fight the ongoing problems of non-execution of these decisions.

Focusing more on the elimination of obstacles to the enforcement of court decisions and ensure effective implementation of the decisions of the courts, should be considered as part of the individual's right to fair trial. The analysis of specific cases of non-execution of judicial practice, in order to predict an alignment and formatting of this relationship with future standards of European law.Bringing innovation as the basis of the above goals the need for reforming and the necessary instruments should be used to improve the current situation of the execution of judgments.

\section{Literature Review and Hypotheses and foreign experiences}

There will be sufficient existence of a legal framework, which simply affirms what is most important are the mechanisms and instruments necessary to ensure the implementation of these norms. If legal norms do not apply then their existence would have no value. ${ }^{3}$ The right to access to court would be illusory if the legal system or its implementation in practice would allow that a final court judgment remain ineffective and unenforceable for a very long time. As noted in internationally recognized documents, full implementation of effective and efficient judicial decisions is essential for states in order to create, strengthen and develop a justice system respectful by all. In addition, when individuals don't trust in the enforceability of decisions, they are likely to rely less on the court for the resolution of disputes and as a result can be returned to other private means to seek justice.

Based on the Constitution of Albania, "The Constitutional Court decides on the final judgment of the individual complaints about violations of their constitutional rights to a fair hearing, after having exhausted all legal remedies to protect these rights." In many cases Albanian citizens who have acquired a right that was denied or violated lose time in different offices just to get that which verdict is legally recognized. ${ }^{4}$ The execution of a final decision of the court is considered as the final stage of implementation of law judicially acquired. Only after completion of this phase can be considered that the individual has fully set in place his right.

Execution properly, effective and timely judicial decisions are of particular importance for member states so that they create, strengthen and develop a strong judicial system and respect. No one in any position cannot and should not allow an individual right recognized by a power indispensable for the existence of the state, like the judiciary, to prevent the action or inaction of his or institution that represents and make legitimate rights of the individual to become unrealistic and illusory. Think how a hundreds Albanian citizens feel disappointment not only them but also their families, after wandering for serial years at the doors of the court, until they take over its decision that recognizes the right of indemnity, after paying the fee for the costs of enforcement, do not take nothing, with an explanation that the budget has no money!

Consider the situation that is created when the chiefs is still wide discretion to appoint and remove from work, even thought the person who has earned the right to be indemnified by the court and must return to the same job or task, and, again minister, director or chief refuses restore the violated right. In all these cases the Albanian citizens, disgusted and offended, will undoubtedly begin to lose confidence in the institutions of his country, will raise the voice of protest against the abuse of power by officials charged with the enforcement of decisions will 'the charge and label them as incapable.All of us who are present and understand that in these cases the state is accused of mismanagement of its affairs.

\subsection{Constituent elements of due process by the constitutional court}

Constituent elements of the right to a basic process developed by the Constitutional Court have been different, although we can not say that they are exhausted from it. These elements are developed on a case by case basis, reflecting the requirements of submitted by individuals, and include such as access to the trial, trial by a court established by law, independent, impartial, reasonable duration of the trial, the right to appeal, the right to protection, the right to participate in the trial itself, equality of arms, the execution of the decision, the reasoning of the decision, etc.

${ }^{3}$ Rezoluta e Konferencave të Ministrave Europiane të Drejtësisë, 4-5 tetor 2001. Marrë nga rekomandimi i Komitetit Europian për Bashkëpunim Ligjor lidhur me zbatimin e vendimeve gjyqësore të vendeve anëtare të Këshillit të Europës.

${ }^{4}$ Vendimi i Gjykatës Kushtetuese të Republikës së Shqipërisë nr. 43 datë 19.12.2007 
${ }^{5}$ The execution of judicial decisions is a final important element of the right to a fair hearing. In evaluating the Court's judgment should not be conceived close, only securing a court decision, but at the end of this process, because a right acquired remain worthless unless implemented through the execution of the decision. ${ }^{6}$ The execution of a final decision of the court is considered as the final stage of implementation of the right to earn a judicially. Only after completion of this phase can be considered that the individual has fully set in place his right. At this stage should not only actively participating parties, debtor and creditor, but the authorities charged with the enforcement of final court. ${ }^{7}$ The role of these bodies is crucial when the debtor refuses to voluntarily execute his obligation towards the creditor. In such cases it may be said that the process of setting in place of a right includes not only the decision violated the court case, but the concrete actions of the responsible bodies charged with the execution of a final court. ${ }^{8}$

\subsubsection{Execution of court decisions as part of the regular judicial process}

H. 1 - Comparing the current situation of execution of court decisions, the greater the number of not executed decisions, the greater the cases of violation of the right to due judicial process, therefore the cost to individuals and the state will suffer.

Enforcement of judicial decisions shall take place within a reasonable time; Enforcement proceedings shall be subject to an effective - not only formal - judicial review making it possible to challenge acts by civil servants delaying or denying enforcement; Non-compliance with a court decision shall give rise to debtors' responsibility under the federal law and a special mechanism must exist to implement civil servants' responsibility for lack of or delay in enforcement.

${ }^{9}$ Constitutional Court has established a practice of her own saying that "execution of the decision constitutes an essential element of the concept of rule of law and the very idea of a fair trial" and that "no state authority cannot call into question the fairness judicial decisions final.Any public body is obliged to take appropriate measures for their implementation "..10 The Court restates that in a case involving the determination of a civil right, the length of proceedings is normally calculated from the start of the proceedings, until the given decision and executed it. Phase executive is considered as a further stage of the same process.

H. 2 - Problems and delays in the execution of court decisions, are dedicated to bureaucracy and indifference of state institutions and supervisory bodies, including to the private sector, pressure of vertical and horizontal interference of political power in the execution of court decisions, incompetence, lack of professionalism, nepotism and personal interests of the bailiff staff, state and international bodies, lack of cooperation and coordination of institutions with bailiff offices, whose omission is a serious obstacle to unjustified even to non-execution of court decision.

Albania presented its application for membership of the European Union on 28 April 2009. Following a request by the Council, the Commission submitted its Opinion on Albania's application in November 2010. In December 2010, the Council endorsed the Commission Opinion's recommendations. In its conclusions, the Council noted that the opening of accession negotiations will be considered by the European Council, in line with established practice, once the Commission has assessed that the country has achieved the necessary degree of compliance with the membership criteria and, in particular, has met the key priorities3 set out in the Commission's Opinion. The Commission's 2012 progress report, like that of 2011, focuses on implementation of these key priorities. (Source: Albanian Progress Report 2011)

$\mathrm{H}$ 3.Defining a new approach to promote debate on various issues related to the full and timely execution court decisions, through measures to fight the ongoing problems of non-execution of these decisions.

The interpretation of un-told principles, are set explicitly in the Constitution, which guarantees evaluated as principles-very important to ensure the implementation of human rights and fundamental freedoms. In these cases we can speak not only for an interpretation of the Constitution, but also to a change in her, as the Court has expanded in other words the essence of the content and spirit of the Constitution.

\footnotetext{
5 The decision of the Constitutional Court of the Republic of Albania no. 49, dated 21.11.2011

${ }^{6}$ The decision of the Constitutional Court of the Republic of Albania no. 11, dated 02.03.2012

${ }^{7}$ The decision of the Constitutional Court of the Republic of Albania no. 13, dated 21.03.2012

8 The decision of the Constitutional Court of the Republic of Albania no. 30, dated 16.05.2012

9Vendime të Gjykatës Kushtetuese nr. 9, datë 02.04.2003; fq. 39 dhe vendimi nr.11, datë 10.03.2003; fq. 47. Përmbledhje e vendimeve, viti 2003

10 Vendime të Gjykatës Kushtetuese nr. 9, datë 02.04.2003; fq. 39 dhe vendimi nr.11, datë 10.03.2003; fq. 47. Përmbledhje e vendimeve, viti 2003 


\subsection{The role of the Constitutional Court to protect the constitutional right to due process}

Throughout our study Constitutional Jurisprudence we find many cases that clearly show how constitutional guarantees of individual rights and freedom, interact with each other and get life through this interaction. In the past 10 years, the Albanian Constitutional Court has interpreted the Constitution broadly and creatively, especially in cases of constitutional protection of human rights. In its decisions, not only are the detailed guarantees mentioned in the Constitution, but also new elements are affirmed guarantee.

Initially, the Constitutional Court did not consider the associated compulsory execution of judicial decisions with Article 42 of the Constitution, which had expressly provided only base pillars of due process, without the exhausted its elements. Moreover, our Constitutional Court had not taken into account either the fact that the European Court has interpreted Article 6 of the European Convention on Human Rights in 1997, the case against Greece Horsbi, in which was stated that, "The execution of a decision of the court if any, should be considered as part of the judicial process in the sense of Article 6 ". In the case of "Qufaj \& Co., Ltd, against Albania ", the Court of Human Rights, found that the Albanian Constitution and the law containing the necessary to guarantee citizens the execution of judgments.

This means that the judge must interpret the right to a fair hearing not only the elements expressly sanctioned by the Constitution, but also beyond. The ability of judges to interpret the Constitution in a creative way is not only welcome in Constitutional law, but also necessary. This makes it possible to resist time a Constitution for centuries. Constitutional Court changed its position on this issue, the decision 6/2006,

\subsubsection{Violation of the constitutional law, cases of infringement. Albania case study and the European Judicial Practice}

In 2000, the Constitutional Court rejected the appeal of a society Qufaj \& Co. sh.pk applicant, stating that not be taken into consideration for the execution of court decisions is outside the jurisdiction of the Constitutional Court. The European Court of Human Rights, in Qufaj \& Co. against Albania, 184clearly argued the opposite, that the right to a fair hearing: would be illusory if a domestic legal system of a Member State shall be allowed a final court judgment, to remain inoperative to the detriment of one party. It would be inconceivable that Article 6.1 should describe in detail procedural guarantees afforded to litigants that are fair, public and protected quick-free execution of court decisions.

The new procedure for enforcement of judgments delivered against the public authorities under the 2005 Law is largely based on the presumption that the responsible state organs (the Federal Treasury with its territorial offices, the Ministry of Finance, the financial departments of regions and municipalities) will henceforth effectively ensure, upon the claimant's request, compliance with judgments. The 2005 Law does not contain any right for claimants to use coercive enforcement mechanisms against the public authorities.

The whole judicial process, often difficult and problematic, there would be no value if not followed by a process that connects directly to the bailiff offices, with its execution or realization of an acquired right. The aim is to critique in order to meet gaps in legislation concerning legal regulation of executive relations.

Focusing more on the elimination of obstacles to the enforcement of court decisions and ensure effective implementation of the decisions of the courts, should be considered as part of the individual's right to fair trial. As in the analysis of specific cases, of non-execution of judicial practice, in order to predict an alignment and formatting of this relationship with future standards of European law. Bringing innovation as the basis of the above goals the need for reforming and the necessary instruments should be used to improve the current situation of the execution of judgments.

\section{Research Goal and data collected}

European Court of Human Rights has about 58 claims against Albania communicated and 50 pending communication, in which the alleged violation of property rights and other rights associated with them. In most cases claim the right to property under Article 1, Protocol 1 of the European Convention on Human Rights associated with claims for the right to fair hearing under Article 6 and the right to effective remedies under Article 13 the ECHR. During 2000-2012 are executed for 20 such cases against Albania, which in 16 cases of human rights violation, the sanction in the amount EUR $6,571,876$ and 1,650 $\mathrm{m} 2$ trualli5. Albania has fully executed 11 decisions, has two decisions in the enforcement process and the process of negotiation for compensation of damages 3 other decisions.

The rule of law and constitutionality are not voluntaristic concepts from the moment of conceptual constitutional choice we make, and the less discretionary. They are fundamental to a majority mindset of real democracy without which cannot exist, and starting from the receipt of the perception that an individual or a certain group in a democratic society 
should accept as legitimate a solution that does not fits with his mindset interests or personal or group concerned. ${ }^{11}$

Execution of decisions within a reasonable time has been the continued focus of the European Court of Human Rights, which in its jurisprudence, consistently, has reaffirmed that the reasonable duration of proceedings must be assessed in light of the circumstances the case, and taking into account the complexity of the case, the conduct of the applicant and the relevant authorities and the applicant's interest. To assess the complexity of the proceedings should be important to all aspects of the matter, including subject matter, the disputed facts and the volume of written evidence.

The complexity of the issue, in balance with the principle of ensuring the proper administration of justice, can justify the considerable length of time. As regards the conduct of the applicant / appellant, the ECHR has held that the use by the applicant of all procedures provided by domestic law, to ensure the protection, cannot be used as evidence against him. As regards the conduct of the authorities, the ECHR has held that even in legal systems, which apply the principle that the procedural initiatives belong to the parties, again the courts have a duty to ensure the trials progress quickly enough. (Decision "Cravcenko against Moldova", ECHR, dated 15.04.2008).

\section{Conclusions and recommendations}

In Albanians actuality are not limited cases where individuals were violated his right to a fair trial, particularly in the area of enforcement of final judicial decisions. Cases of constitutional jurisprudence indicates that the last five years we have received over 10 requests for findings of infringement of the constitutional right to a fair hearing, as a result of the failure of a final court decision. The main causes of this violation were mostly the central and local government institutions and bailiff offices, which with their actions and inactions have caused delays and unjustified delay not legitimate. Although the decisions of the Constitutional Court are final, the final and effective on the day of its publication in the Official Journal, enforcement of law has a lot to be realized. Albanian practice has also been many cases where the Albanian state was sentenced to indemnify individuals due to the failure of a final court judgment. ${ }^{12}$ Even in these cases, the state has issued again as pretext for failure to execute the decisions of the financial impossibility.

Reform of the justice system and especially in the field of execution of court decisions starting in 2008 with the adoption of the law "On private bailiff service", and so on has undergone a significant improvement to the winning subjects giving them the opportunity to freely select the efficient bailiff service and avoid monopolization of this service only from state offices. However this does not solve all problems, much more is needed to be done .Bailiff offices should rely more in their activity from the state institutions such as the police, local government. Local Offices of Real Estate Registration, Second Level Banks and State Police are the main pillars that sustain all service and if these do not respond in time and quality that needs bailiff for execution, these make the work harder. Which monetary amount is to be sufficient at least for the execution of the obligation in installments, a fact which is often accepted by the creditor only to continue executions. Should be checked more informal income, reducing the latter will be possible sequestration of assets of the debtor parties. In this paper research we are recommend these findings:

1. Strengthening the position of bailiff law.

2. Strengthening the independence and insularity of politics and government.

3. Perform electronic system for online access (that traces) by bailiffs (only for parties that have active folder) on the Bank Level II COIPR, Civil Status, DRSh.T.Rr etc. that help identify the debtor and its assets.

4. Limited to cases that prosecutors and police apply pressure on the bailiff that has a super high level of these in terms of civil procedural and beyond.

5. Have probably Department / Sector specific (unlimited daily activity of the Police) depending on the county Police Department Support exclusively for the execution of any matter.

6. The government cares about every Bailiff problematic, because a decision does not apply the court and justice worthless.

7. The practice of appropriation installment debtors Budget Institutions settlement obligations and liabilities with corrupt preferences, but the legality of the repayment by the chronology are presented for execution of what has come earlier to what came later with the percentage sequence progressive chronological.

\footnotetext{
${ }^{11}$ National Conference "The execution of judicial decisions for the protection of individual rights" Ledi Bianku Page 59

${ }^{12}$ Çështja Qufaj kundër Shqipërisë, 54268/00, 18 nëntor 2004. 


\section{References}

Resolution of the Conference of European Ministers of Justice, 4 to 5 October 2001.Taken from the recommendation of the Committee on Legal Co-operation on the implementation of judgments of the member states of the Council of Europe. Hasan ECHR decision against Bulgaria and Chaus, no 30985/96, pg 23,35,56 87.

The decision of the Constitutional Court of the Republic of Albania, no. 6 dated 31.03.2006.

The issue Qufaj against Albania, 54268/00, 18 November 2004.

The ECHR decision Romashov v. Ukraine, no. 67534, 27 July 2004; Shvedov against Russia, Nr.69306/01, 20 October 2005. See also the decision of this Court, Hornsby v. Greece, 19 March 1997

42 and 142/3 of the Constitution and Article 6 of the ECHR issue against the Republic of Albania

The other issue Bershiri against the Republic of Albania

Ramiz issue Daut against the Republic of Albania

Summary of decisions of the Constitutional Court of the Republic of Albania, year 2007, pp.23,58,48,65.

The raport for Albania is Mr Nikolaos Chountis. Enlargement Strategy and Main Challenges 2012-2013, COM(2012) 600.

The key priorities concern the following areas: the proper functioning of parliament; adopting reinforced majority laws; appointment procedures and appointments for key institutions; electoral reform; the conduct of elections; public administration reform; the rule of law and judicial reform;

The decision of the Constitutional Court of the Republic of Albania, no. 6 on 31/03/2006

The decision of the Constitutional Court of the Republic of Albania, no. 43 dated 19.12.2007

The decision of the Constitutional Court of the Republic of Albania, no. 1 dated 19/01/2009

The decision of the Constitutional Court of the Republic of Albania, no. 8 Printing date 03/23/2010 ILAR, Tirana 2011, p. 122.

The decision of the Constitutional Court of the Republic of Albania no. 12, dated 15.04.2011

The decision of the Constitutional Court of the Republic of Albania no. 35, dated 27.10.2010

The decision of the Constitutional Court of the Republic of Albania no. 23, dated 17.05.2010

The decision of the Constitutional Court of the Republic of Albania no nr.14, dated 15.04.2010

The decision of the Constitutional Court of the Republic of Albania no. 50, dated 22.11.2011

The decision of the Constitutional Court of the Republic of Albania no. 2, dated 01.02.2011

The decision of the Constitutional Court of the Republic of Albania no. 7, dated 27.02.2012

The decision of the Constitutional Court of the Republic of Albania no. 10, dated 01.03.2012

The decision of the Constitutional Court of the Republic of Albania no. 11, dated 02.03.2012

The decision of the Constitutional Court of the Republic of Albania no. 13, dated 21.03.2012

The decision of the Constitutional Court of the Republic of Albania no. 30, dated 16.05.2012

The decision of the Constitutional Court of the Republic of Albania no. 49, dated 26.07.2012

The decision of the Constitutional Court of the Republic of Albania no. 56, dated 21.12.2012

The decision of the Constitutional Court of the Republic of Albania no. 4, dated 20.02.2013 